126

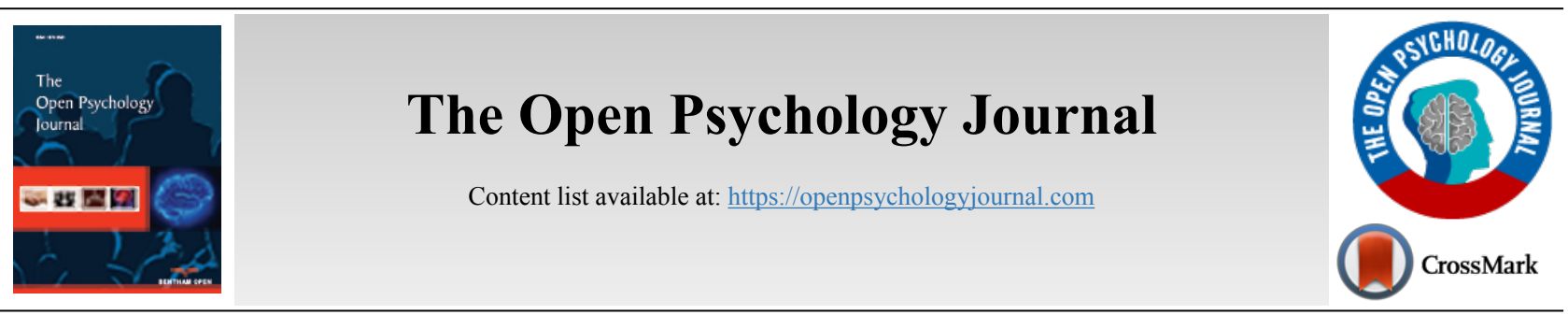

RESEARCH ARTICLE

\title{
Job Satisfaction as a Mediator for the Influence of Transformational Leadership and Organizational Culture on Organizational Citizenship Behavior
}

\author{
Neil Aldrin ${ }^{1, *}$ and Kuncono Teguh Yunanto ${ }^{2}$ \\ ${ }^{I}$ Bhayangkara Jakarta Raya University, Faculty of Psychology, Jakarta, Indonesia \\ ${ }^{2}$ Persada Indonesia University YAI, Faculty of Psychology, Jakarta, Indonesia
}

\begin{abstract}
:
Background:

This study aims to explore the effect of transformational leadership and organizational culture on organizational citizenship behavior and see whether job satisfaction functions as a good mediator

Methods:

By using a quantitative approach, the data collection tool uses a psychological scale, the research respondents $(\mathrm{N}=232)$ are employees and leaders of one company.

Results:

The results of the study show that job satisfaction functions as a mediator of the influence of transformational leadership and organizational culture on organizational citizenship behavior.

\section{Conclusion:}

By applying transformational leadership style accompanied by building a good organizational culture the organization has strong capital to foster employee organizational citizenship behaviour. This study also provides empirical evidence of the influence of these two variables on organizational citizenship behaviour through job satisfaction.
\end{abstract}

Keywords: Job satisfaction, Transformational leadership, Organizational culture, Organizational citizenship behaviour, Human resources, Unemployment.

\begin{tabular}{|l|l|l|l|}
\hline Article History & Received: December 18, 2018 & Revised: February 13, 2019 & Accepted: April 22, 2019 \\
\hline
\end{tabular}

\section{INTRODUCTION}

The occurrence of the economic crisis in America which spread throughout the world had a negative impact on most corporate organizations throughout the world. This economic crisis forced companies to make various changes that could potentially create future uncertainty for most employees. The worst thing is causing a lot of unemployment that can disrupt mental health $[1,2]$. Even though this has passed, the company's organizational attention to the psychological situation of employees remains a concern.

This is because human resources are the most important element in industrial and organizational development. It is related that human resources are one of the perpetrator factors

\footnotetext{
* Address correspondence to this author at the Bhayangkara Jakarta Raya University, Faculty of Psychology, Jakarta, Indonesia;

E-mail: neil.aldrin@dsn.ubharajaya.ac.id
}

for activities within the organization. Every organization has set certain goals to be achieved. To achieve these, the organization is very dependent on the ability of its human resources to be able to move the organization's wheels in a predetermined direction. Therefore, organizations need appropriate strategic planning, so that success can be achieved [3]. To achieve the desired target of the organization, it requires employees who can help each other in doing the work together. Most people do their work based on their own work. Not many people are ready to serve the organization in matters that are outside the scope of his work. This includes helping and caring for other employees in the organization. Organizational Citizenship Behavior (OCB) is a form of behavior that is a choice and initiative individually and not related to a rigid system to increase the effectiveness of the company [4].

There are important reasons why companies must be concerned about employee's job satisfaction, which can be 
classified according to the focus of organizational goals. Employees are the main and important element in the organization to achieve organizational goals. The thoughts, desires, and emotions that employees have can influence their attitude towards their work. Therefore, this study places employee job satisfaction in a central position that has an impact on employee OCB. To generate employee satisfaction, the factors that influence employee satisfaction need to get company's attention.

Every organization has vision and mission that describes values and beliefs, so culture is formed in the organization. Organizational culture is the unique environment of an organization, that develops from the beliefs, assumptions, and values of people in that organization, as well as their way of interacting with each other [5]. Although leaders are the ones who direct the culture of an organization, the established culture of an organization will influence what kind of leadership is possible for that organization [6]. This is in line with the transformational leadership theory in which this theory emphasizes change agents who dare to start, establish, and implement policies in a new direction that are based on innovative ideas and visions [7].

Leadership in organizations is a management approach that focuses on and works together for what is best for individuals and groups. Leaders must have the potential to control groups of individuals and be ready to face various problems and challenges they will face. Speaking of leadership problems is inseparable from what is known as a leadership style, where transformational leadership is one of them. Effective leadership involves how to influence others so that they are motivated to contribute to achieving group goals. The advantages and disadvantages are owned by each leadership style in managing the people in the organization. But the point is how the style can be in line with the balance of organizational and cultural goals [8].

Research conducted by Nohe \& Hertel [9], explaining the relationship between transformational leadership behavior and OCB seen from positive work attitude behavior, resulted in job satisfaction, while other studies found that transformational leadership had no relationship or influence on OCB [10 - 12]. This attracted the attention of researchers on the role of job satisfaction as a mediator of the influence of transformational leadership on OCB.

In general, this study aims to examine the effect of transformational leadership and organizational culture on organizational citizenship behavior through job satisfaction. Specifically, this study aims to see the effect of (1) job satisfaction on organizational citizenship behavior, (2) the direct influence of transformational leadership on organizational citizenship behavior, (3) the influence of transformational leadership on organizational citizenship behavior through job satisfaction as a mediator, (4) direct organizational culture towards organizational citizenship behavior (5) influence of organizational culture on organizational citizenship behavior through job satisfaction as a mediator.

\section{LITERATURE REVIEW}

\subsection{Organizational Citizenship Behavior}

According to Robbins \& Judge [13], Organizational Citizen-ship Behavior (OCB), is the behavior of individual or individuals who are voluntary and not part of the formal conditions of work but can improve the effective functioning of the organization. Organ [14]: Organizational Citizenship Behavior is the behavior of individuals who have the freedom to choose, which is indirectly or not explicitly associated with the reward system, and contributes to the effectiveness and efficiency of organizational functions. Organizational Citizenship Behavior is work behavior that exceeds work requirements and contributes to organizational success. OCB behavior is displayed by helping colleagues and customers, doing extra work if needed, and helping to solve problems in improving products and procedures.

According to Graham [15], there are three dimensions of Organizational Citizenship Behavior, namely: (1). Obedience, the willingness of employees to accept and comply with the rules and procedures that exist within the organization, (2). Loyalty, the willingness of employees to place their personal interests for organizational purposes, (3). Participation, the willingness of employees to actively develop all aspects of organizational life.

Meanwhile, according to Podsakoff et al. [16], there are seven dimensions of Organizational Citizenship Behavior, namely: (1). Supportmanship, is the willingness or desire to tolerate inconvenience that arises and work determination without complaint. (2). Civic virtue, is an employee's commitment to the company as a whole, such as attending meetings, delivering ideas, and actively participating in activities organized by the organization. (3). Helping behavior, is an employee's voluntary behavior in helping coworkers or preventing problems at work. (4). Organizational loyalty, is a form of em-ployee loyalty to the company such as displaying a positive image about the company, defending the company from external threats, and trying to achieve organizational goals, (5). Organizational compliance, is the behavior of individuals in complying with all organizational rules, procedures and regu-lations even though not in supervision, (6). Individual initiative, is a form of encouragement from within the individual to carry out the task beyond the standard of duty that has been set, (7). Self development, is an individual's voluntary behavior to increase knowledge, skills and capability, like attending training, seminars, or following the latest developments related to his work.

\subsection{Job Satisfaction}

Through job satisfaction we know how many individuals are happy with their work. Many people studied job satisfaction to analyse organization behavior. Towards better performance for motivation and encouragement of employees is job satisfaction belongs to one of the important component [17]. The organizational structure is a very important factor for employee satisfaction and employee perceptions are generated based on this [18].

To have job satisfaction we have to take care of various factors such as the work itself, supervision, salary, promotion, 
relationships with colleagues and opportunities for promotion [19]. Furthermore, compensation has a significant impact on the level of employee job satisfaction. According to the results obtained from the study [20] there is a positive and strong relationship between leadership style and job satisfaction. There are three indicators in job satisfaction expressed by Hasibuan [21], (1). the work itself, (2). discipline, and (3). work performance.

\subsection{Organization Culture}

The concept of organizational culture has been used since 1970 for practical purposes, identifying and promoting best practices in organizations. Its use in this case is often seen as a result of efforts to explain the success of Japanese automotive and electronic producers of their American rivalry during the 1970s. Organizational culture, then, consists of more aspects such as behavior patterns and observable symbols and ceremonies, as well as deeper and fundamental values and assumptions, assumptions and beliefs.

Some believe that changing the visible aspects of an organizational culture, for example the rituals, can change the organizational culture. Organizational culture is an important and pervasive concept in terms of its impact on organizational change programs [22].

The culture itself is a group of people who live in the same place and have the same attitude and behavior. The influence and interaction between employees and certain institutions, organizations or services in which they work describe culture in organizational analysis [23]. Some cultural characteristics can function to increase or inhibit the tendency to innovate within the company. McLean [24] discusses that organizational culture is related to the characteristics and dimensions of an organization's climate related to support or obstacles to creativity and innovation.

According to Suifan and Al-Janini [25], there are three levels of culture, (1). Artifacts, (2). Beliefs and values sought, and (3). The underlying assumptions. In their workplaces, there are three different cultures, namely their nationality, their work and their organizational culture which influence the behavior of employees [26].

\subsection{Transformational Leadership}

Transformational leadership is one of several leadership styles proposed by Robbins and Judge [27]. Transformational leadership behavior in a multifaceted environment where middle managers are stimulated to be creative, flexible and innovative in their leadership style. The effective role of managers and leaders in change and transformation cannot be avoided in organizations. By coordinating employees and integrating all system components, those leaders are ready to achieve an ideal perspective [28].

Transformational leadership, according to Burns [29], is “a process where leaders and subordinates help each other to reach higher level of motivation and morals." Furthermore according to him, the transformation approach creates significant changes in one's life and organization. Where this redesigns perceptions and values and changes the expectations and aspirations of the employees involved in the organization. This is a process to be able to develop their organization to its goals. It also creates and builds people in the organization to maximum performance [30].

Transformational leaders, according to Robbins \& Judge [31], are those who "inspire followers to transcend their own interests" and "are able to have a profound effect on followers". Transformational leadership is the most basic element of a transformation program which means it can succeed or fail. Transformational strategy is a technique, which practically causes changes in various fields [32]. Van der Voet, et al., [33] states that lower or higher levels of transformational leadership provide equal support for employees in the planned process. A significant role in this leadership in encouraging cognitive processes to develop the creativity of people in the organization [34, 35]. Four elements of transformational leadership proposed by Bass [36], as follows; (1) Individual Considerations, namely the extent to which leaders can understand and want to listen to followers' concerns and needs, and act as mentors or trainers for followers. Transformational leaders also provide empathy, support, keep communication open and place challenges in the face of followers, (2) Intellectual stimulation, the extent to which leaders are able to stimulate and encourage followers' creativity. For leaders, transformational learning is are unexpected values and situations that are seen as opportunities, (3) Inspirational motivation, the extent to which leaders articulate an attractive vision and are able to inspire followers. Leaders who are able to motivate and inspire will give their followers high standards, an optimistic attitute about future goals, and help them give meaning to the task at hand. Meanwhile, followers must have a strong goal and motivation to act. Goals and meanings will provide energy that will encourage organizational members to achieve organizational goals. The vision of a leader needs to be supported with communication skills to make that vision "understandable, appropriate, strong and attractive." Followers want to invest more effort in their tasks, they have encouragement and optimism about the future and are confident in their abilities, (4) Ideal Influence, providing role models for high ethical behavior, instilling pride, gaining respect and trust from followers.

\subsection{The Effects of Job Satisfaction Towards Organizational Citizenship Behavior}

Job satisfaction functions as a measure of employees in assessing the positive or negative work [37]. George and Jones [38] said that job satisfaction consists of beliefs and feelings that individuals feel about their work.

Job satisfaction is an important component in motivating and encouraging employees to have better performance [39]. Employees who have a positive assessment of their work have the urge to do the best for the organization, and also work beyond what is their main task. As said by Podsakoff, Mackenzie [40], employees who are satisfied with their work will have a strong motivation to perform organizational citizenship behavior. Furthermore Robbin and Judge [31] observe that job satisfaction can foster organizational citizenship behavior. 


\subsection{The Effects of Transformational Leadership Towards Organizational Citizenship Behavior}

Employees are expected to show reciprocal behavior in response to perceived leader behavior. It is well known that employees behavior is an important constituent of their overall behavior and has an important influence on the performance of their work [41]. Transformational leadership can encourage employees to overcome their interests and strive to achieve common goals [36]. Managers who use transformational leadership styles motivate members through leadership dimensions, which can be an ideal effect of inspirational motivation and rational stimulation [42]. In his study, Jahangir et al. [43] found that leadership style has an influence on organizational citizenship behavior of employees.

In another study, the central role of job satisfaction as a factor that influences organizational citizenship behavior and also as a factor that is influenced by transformational leadership puts job satisfaction as a mediator variable relationship between transformational leadership and organizational citizenship behavior. Studies conducted by Nguni, Sleegers, and Denessen [44] have obtained empirical evidence of the role of mediator job satisfaction in the relationship of transformational leadership with organizational citizenship behavior.

\subsection{1. $\mathrm{HI}$}

There is an effect of job satisfaction on organizational citizenship behavior.

\subsection{2. $\mathrm{H} 2$}

There is a direct influence of transformational leadership on organizational citizenship behavior.

\subsection{3. $\mathrm{H3}$}

There is an influence of transformational leadership on organizational citizenship behavior through job satisfaction as a mediator.

\subsection{The Effects of Organizational Culture Towards Organizational Citizenship Behavior}

A strong culture will show an agreement between its members, this forms an attachment, loyalty, and commitment which results in a decrease in the desire of employees to leave the organization [31]. The study of organizational culture is not new, but the study of organizational culture remains challenging. As Schein [6] said, organizational culture was developed from time to time as an effort by organizational members to adapt both externally and internally to achieve organizational goals. The link between organizational culture and organizaitional citizenship behavior has also been carried out. Among them produces findings that organzational culture is related to organizational citizenship behavior $[45,46]$. The role of job satisfaction in mediating organizational culture with organizational citizenship behavior is an interesting study. Employees who perceive organizational culture positively will feel comfortable at work, and also feel satisfied with their work, this will then encourage employees to do organizational citizenship behavior. This is supported by several studies that found that job satisfaction mediates the relationship of organizational culture with organizational citizenship behavior $[47,48]$.

\subsection{1. $\mathrm{H4}$}

There is a direct influence of organizational culture on organizational citizenship behavior.

\subsection{2. $\mathrm{H5}$}

There is an influence of organizational culture on organizational citizenship behavior through job satisfaction as a mediator.

Based on the hypotheses that have been formulated previously, the major hypothesis formulated in this study is as follows:

\subsection{3. $\mathrm{H6}$}

There is an influence of transformational leadership and organizational culture on organizational citizenship behavior through job satisfaction as a mediator.

\section{MATERIALS AND METHODS}

The research was conducted with a quantitative approach. Data analysis techniques in this study use path analysis. To get the value of direct and indirect effects, regression analysis with intervening variables is used. This study uses a quantitative approach to test 6 hypotheses, data collection tools using a psychological scale, research respondents are employees and leaders of one company. Methods of data analysis using Structural Equation Models based on variants or Variance Based-SEM with consideration in accordance with the purpose of research and abnormal data distribution.

\subsection{Research Participants}

Respondents in this study were employees at one of the companies in Indonesia, amounting to 232 respondents consisting of employees and company managers. Based on descriptive analysis of the research data of as many as 232 respondents, the following results were obtained (Table 1):

\section{Table 1. Subject data based to criteria.}

\begin{tabular}{|c|c|c|}
\hline Research Subject & Total & \% \\
\hline Manager & 98 & 40 \\
\hline Employees & 134 & 60 \\
\hline
\end{tabular}

A total of 98 people or $40 \%$ of the total respondents in this study were managerial, while 134 people or $60 \%$ of the total respondents were employees, so the total respondents were 232 people (Table 2 ).

Table 2. Subject data based to gender.

\begin{tabular}{|c|c|c|}
\hline Research Subject & Total & \% \\
\hline Male & 127 & $55 \%$ \\
\hline Female & 105 & $45 \%$ \\
\hline
\end{tabular}

A total of 127 people or $55 \%$ of the total respondents in this study were male, while 105 people or $45 \%$ of the total respondents were female, so the total respondents were 232 people. 
To collect research data, researchers developed a research instrument using a Likert type psychological scale. There are four scales developed and tested. After the instrument trial, transformational leadership scale has reliability coefficient 0.905, organizational culture scale has a coefficient of reliability 0.916 , job satisfaction scale has a reliability coefficient of 0.97 , and organizational citizenship behavior scale has a reliability coefficient of 0.910 .

\subsection{Measuring Instruments}

To collect research data, researchers developed a research instrument using a Likert type psychological scale. There are four scales developed by researchers and have been tested.

Transformational leadership scale was developed based on individual aspects, motivation, and ideal according to Bass [36], the scale of organizational culture was developed based on aspects of artifacts, beliefs, and assumptions according to Schein [6], Scale of work satisfaction scale was developed based on aspects of work, discipline, and achievement according to Hasibuan [21], the scale of organizational citizenship behavior was developed based on aspects of obedience, loyalty, and participation according to Graham [39].

Transformational leadership has a composite reliability coefficient of 0.869 , organizational culture scale has a composite reliability coefficient 0.904 , job satisfaction scale has reliability coefficient 0.897 , and organizational citizenship behavior scale has a reliability coefficient of 0.953 .

\section{Table 3. Description of research data.}

\begin{tabular}{|c|c|c|c|c|}
\hline- & Mean & SD & Skewness & Kurtosis \\
\hline TL & 47.022 & 7.501 & 0.021 & -0.487 \\
\hline ID & 15.616 & 2.993 & -0.351 & -0.411 \\
\hline MO & 15.517 & 3.044 & -0.358 & -0.303 \\
\hline IN & 15.888 & 2.990 & -0.578 & 0.066 \\
\hline OC & 47.591 & 7.755 & -0.280 & -0.135 \\
\hline AS & 15.694 & 3.180 & -0.617 & 0.161 \\
\hline BE & 15.737 & 2.961 & -0.460 & -0.132 \\
\hline AR & 16.159 & 2.772 & -0.707 & 0.868 \\
\hline JS & 47.522 & 8.311 & -0.275 & -0.385 \\
\hline PR & 15.513 & 3.398 & -0.448 & -0.464 \\
\hline DC & 15.703 & 3.266 & -0.523 & -0.383 \\
\hline JI & 16.306 & 2.965 & -0.847 & 0.395 \\
\hline OCB & 48.401 & 7.807 & -0.516 & 0.119 \\
\hline PN & 16.091 & 2.742 & -0.527 & 0.233 \\
\hline LO & 16.056 & 2.864 & -0.574 & -0.004 \\
\hline OB & 16.254 & 2.765 & -0.704 & 0.280 \\
\hline
\end{tabular}

Bass [36] TL, Transformational Leadership, (ID, Individual, MO, Motivation, IN, Intellectual); Schein [6] OC, Organization Culture (AS, Assumption, BE, Believe, AR, Artifacts); Hasibuan [21] JS, Job Satisfaction (PR, Achievement, DC, Discipline, JI, Job Itself); Graham [15] OCB, Organizational Citizenship Behavior (PN, Participation, LO, Loyalty, OB, Obedient)

\subsection{Statistical Analysis}

Descriptive statistical methods to describe the research data used mean, media, and standard deviation, to determine the normality of the data used multivariate normality testing using SPSS 22 software. Data analysis methods used to test hypotheses are structural equation modeling based on variants or variants based on SEM (VB-SEM) by using SmartPLS software, this VB-SEM method is chosen with the consideration that the data distribution is not normal.

\section{RESULTS}

In this study, a measure of central tendency uses the mean, while dispersion measures use standard deviations. For transformational leadership variables obtained mean of 47.02 and SD of 7.50, organizational culture variables obtained mean of 47.59 and SD of 7.75, variable job satisfaction obtained mean 47.52 of SD and 8.310, and for organizational citizenship behavior variables obtained mean 48.40 of SD 7.80 (Table 3).

In general, this study aims to examine the effect of transformational leadership and organizational culture on organizational citizenship behavior through job satisfaction, specifically this study wants to test six hypotheses. Data analysis consists of two stages, namely the Outer Model and Inner Model Analysis.

\subsection{Outer Model Analysis}

The first outer model analysis is convergent validity testing. Convergent validity is seen from the value of loading factors. The outer loading value is shown in the following Table 4:

Table 4 shows that all loading factors on each variable have a value above 0.7 , this indicates good convergence of validity.

Table 4. Outer loading of each variable.

\begin{tabular}{|c|c|c|c|c|}
\hline- & JS & OC & OCB & TL \\
\hline DC & 0.860 & - & - & - \\
\hline JI & 0.866 & - & - & - \\
\hline PR & 0.862 & - & - & - \\
\hline AR & - & 0.874 & - & - \\
\hline AS & - & 0.857 & - & - \\
\hline BE & - & 0.880 & - & - \\
\hline LO & - & - & 0.926 & - \\
\hline OB & - & - & 0.928 & - \\
\hline PN & - & - & 0.944 & - \\
\hline ID & - & - & - & 0.823 \\
\hline IN & - & - & - & 0.829 \\
\hline MO & - & - & - & 0.838 \\
\hline
\end{tabular}

DC: Discipline, JI: Job Itself, PR: Achievement, AR: Artifacts, AS: Assumption, BE: Believe, LO: Loyalty, OB: Obedients, PN: Participation, ID: Individual, IN: Intellectual, MO: Motivation

Tabel 5. Average variance extracted.

\begin{tabular}{|c|c|}
\hline- & AVE \\
\hline JS & 0.744 \\
\hline OC & 0.758 \\
\hline OCB & 0.870 \\
\hline TL & 0.689 \\
\hline JS: Job Satisfaction, OC: Organizational Culture, OCB: Organizational
\end{tabular}

Citizenship Behavior, TL: Transformational Leadership

In addition, it is also known that the value of Average Variance Extracted (AVE) (Table 5) of each variable in this study has a value above 0.5 , so Convergence validity is good. 
AVE values are shown in the following table:

Outer Model Analysis the second is discriminant validity testing. Based on the Fonell-Larcker Criterion test it can be seen that the value of square root AVE is greater than the correlation of each construct.

The results shown in Table 6 show that the instrument has good discriminant validity because the square root AVE numbers in parentheses are greater than the correlation of each construct.

\section{Table 6. Fornell-larcker criterion.}

\begin{tabular}{|c|c|c|c|c|}
\hline- & JS & OC & OCB & TL \\
\hline JS & $(0.863)$ & - & - & - \\
\hline OC & 0.800 & $(0.870)$ & - & - \\
\hline OCB & 0.693 & 0.565 & $(0.933)$ & - \\
\hline TL & 0.709 & 0.661 & 0.526 & $(0.830)$ \\
\hline
\end{tabular}

JS: Job Satisfaction, OC: Organizational Culture, OCB: Organizational Citizenship Behavior, TL: Transformational Leadership

In addition, the loading value of each aspect of the variable is greater than the cross loading value of each aspect of the other variables. As shown in the following table (Table 7), where the value of loading each aspect on one variable is bold:

Tabel 7. Cross loading of each variable.

\begin{tabular}{|c|c|c|c|c|}
\hline- & JS & OC & OCB & TL \\
\hline DC & 0.860 & 0.663 & 0.608 & 0.620 \\
\hline JI & 0.866 & 0.722 & 0.623 & 0.602 \\
\hline PR & 0.862 & 0.685 & 0.561 & 0.613 \\
\hline AR & 0.691 & 0.874 & 0.477 & 0.576 \\
\hline AS & 0.719 & 0.857 & 0.486 & 0.587 \\
\hline BE & 0.680 & 0.880 & 0.512 & 0.561 \\
\hline LO & 0.653 & 0.542 & 0.926 & 0.475 \\
\hline OB & 0.626 & 0.505 & 0.928 & 0.494 \\
\hline PN & 0.660 & 0.534 & 0.944 & 0.501 \\
\hline ID & 0.537 & 0.492 & 0.358 & 0.823 \\
\hline IN & 0.654 & 0.649 & 0.482 & 0.829 \\
\hline MO & 0.560 & 0.485 & 0.454 & 0.838 \\
\hline
\end{tabular}

DC: Discipline, JI: Job Itself, PR: Achievement, AR: Artifacts, AS: Assumption, BE: Believe, LO: Loyalty, OB: Obedients, PN: Participation, ID: Individual, IN: Intellectual, MO: Motivation

Based on the results of Composite Reliability analysis the transformational leadership scale has a coefficient of 0.869 , the scale of organizational culture has a coefficient of 0.904 , the scale of job satisfaction has a coefficient of 0.897 , and the scale of organizational citizenship behavior has a coefficient of 0.953 . The four scales have reliability above 0.7 , so all four scales have good reliability.

\subsection{Inner Model}

The next analysis is an analysis of the inner model that is intended to see the influence between the variables studied. The results of the analysis of the model obtained results as shown in Fig. (1) here:

Based on the first hypothesis testing obtained $\beta=0.638$ and $\mathrm{p}<0.05$, it can be concluded that there is a direct effect of job satisfaction on organizational citizenship behavior. In other words it can be concluded that job satisfaction is a good predictor for the formation of organizational citizenship behavior.

Based on the testing of the second hypothesis obtained $\gamma=$ 0.066 and $p>0.05$, it can be concluded that there is no significant direct influence of transformational leadership on organizational citizenship behavior. These results prove that organizational citizenship behavior will not appear automatically only because leaders apply transformational leadership styles.

Based on the third hypothesis testing, indirect effect $\left(\gamma_{\text {indirect }}\right.$ $=0.204)$ is greater and significant compared to its direct influence $\left(\gamma_{\text {direct }}=0.07\right)$, thus it can be concluded that job satisfaction functions as a mediator of the influence of transformational leadership on organizational citizenship behavior. Transformational leadership applied by superiors will have an impact on employee job satisfaction which in turn can foster employee organizational citizenship behavior. In other words transformational leadership must be able to generate

satisfaction for employees in order to foster organizational citizenship behavior. The results of the analysis of direct and indirect effects are as follows (Table 8):

Table 8. Direct indirect effect.

\begin{tabular}{|c|c|c|c|c|}
\hline \multirow{2}{*}{-} & \multicolumn{2}{|c|}{ Direct Effect } & \multicolumn{2}{c|}{ Indirect Effect } \\
\cline { 2 - 5 } & $\boldsymbol{\beta} / \boldsymbol{\gamma}$ & sig & $\boldsymbol{\gamma}$ & sig \\
\hline $\mathrm{JS} \rightarrow \mathrm{OCB}$ & 0.638 & 0.000 & & \\
\hline $\mathrm{TL} \rightarrow \mathrm{OCB}$ & 0.066 & 0.381 & 0.204 & 0.000 \\
\hline $\mathrm{OC} \rightarrow \mathrm{OCB}$ & 0.011 & 0.905 & 0.376 & 0.000 \\
\hline
\end{tabular}

Based on the fourth hypothesis testing obtained $\gamma=0.011$ and $p>0.05$, it can be concluded that there is no significant direct influence of organizational culture on organizational citizen-ship behavior. Like transformational leadership, this result proves that organizational citizenship behavior will not appear automatically only because organizational culture is perceived positively by employees.

As shown in Table 8, based on the fifth hypothesis testing, indirect effect was obtained $\left(\gamma_{\text {indirect }}=0.376\right)$, bigger and more significant than the direct effect $\left(\gamma_{\text {direct }}=0.011\right)$, thus it can be concluded that job satisfaction functions as a mediator of organizational culture influence on organizational citizenship behavior. Organizational culture that is built will affect employee job satisfaction which in turn can foster employee organizational citizenship behavior. In other words, the organizational culture that is built must be able to generate satisfaction for the employee to be able to foster organizational citizenship behavior. 


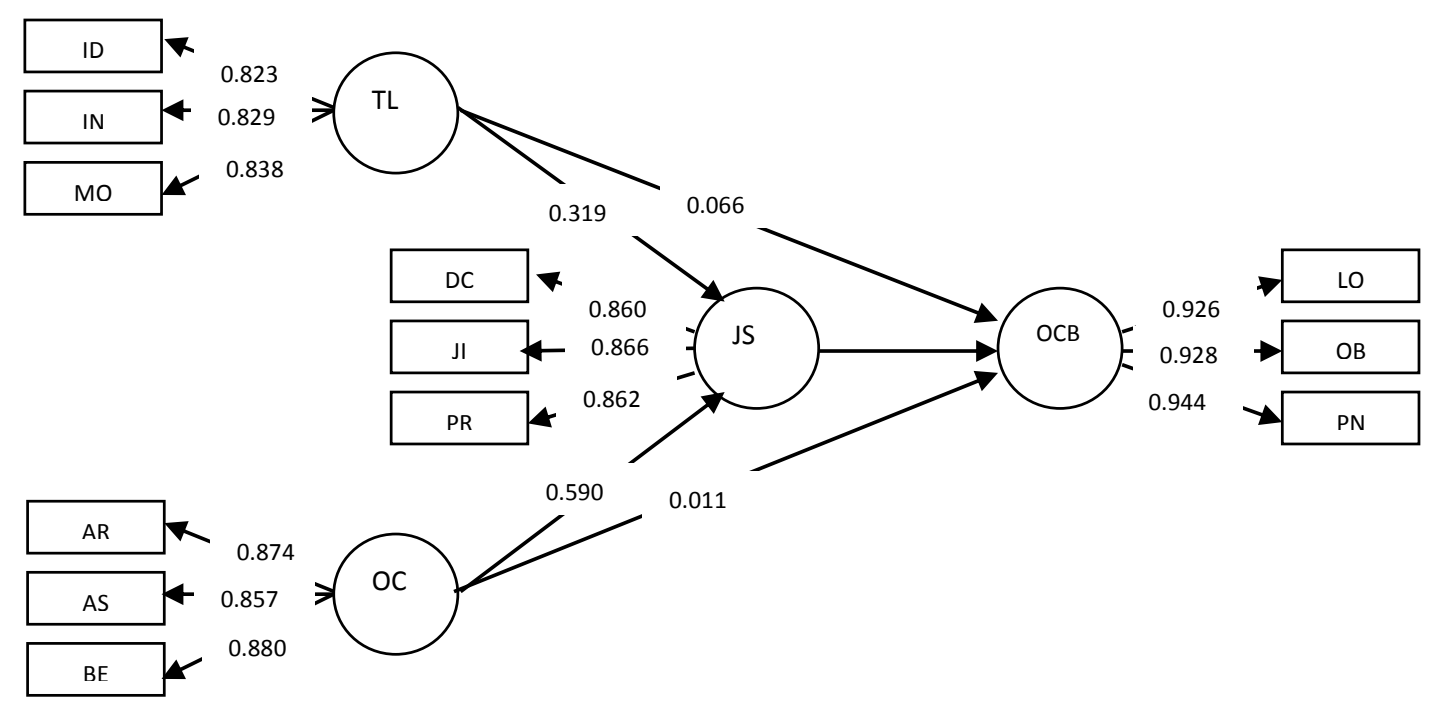

Fig. (1). Path Model.

Bass [36] TL, Transformational Leadership, (ID, Individual, MO, Motivation, IN, Intelectual); Schein [6] OC, Organization Culture (AS, Assumption, BE, Believe, AR, Artifacts); Hasibuan [21] JS, Job Satisfaction (PR, Achievement, DC, Discipline, JI, Job itself); Graham [15] OCB, Organizational Citizenship Behavior (PN, Participation, LO, Loyalty, OB, Obedient)

Based on the goodness of fit model obtained by SRMR of 0.075 lower than 0.08 , the model is said to be fit, so the results of testing on the 6th hypothesis concluded that job satisfaction functions as a mediator of the influence of transformational leadership and organizational culture on organizational citizenship behavior.

\section{DISCUSSION}

\subsection{Transformational Leadership and Organizational Citizenship Behavior}

The results of previous studies found that transformational leadership is associated with behavioral organizational citizenship at Intercollegiate Athletics [49], and findings in research conducted by Nguni, Sleegers, and Denessen [44] found that job satisfaction is a mediator of the effects of transfor-mational leadership on organizational citizenship behavior for teachers in Tanzania. In line with that study, in this study found that there was no direct influence of transformational leader-ship on organizational citizenship behavior, but the effect of transformational leadership on organizational citizenship behavior must be through job satisfaction in employees of one company in Indonesia. Other findings such as research conducted by Wang et al. [50] found that transformational leadership on organizational citizenship behavior was mediated by exchange member leaders. This finding confirms that transformational leadership does not directly impact organiza-tional citizenship behavior but through other variables that have a direct effect on it.

Meanwhile research conducted by Podsakoff et al. [40] found that transformational leadership has both a direct and indirect effect on organizational citizenship behavior. The diversity of the results of some of these findings explains the need for further studies related to the study in the future.

\subsection{Organizational Culture and Organizational Citizenship Behavior}

Several previous studies prove that organizational culture correlates with organizational citizenship behavior [51, 52], whereas in this study found that organizational culture perceived positively by employees does not automatically encourage employees to carry out organizational citizenship behavior, but the organizational culture that is perceived positively by employees will foster employee job satisfaction which then this satisfaction will have implications for organizational citizenship behavior of employees.

The findings in this study as well as previous findings explain that organizational culture created by the organization will have an impact on employees' satisfaction in their work, satisfaction in the work that will build or foster the desire of employees to do something more than what is the responsibility of their work. So as to foster organizational citizenship behavior, organizational employees can build a good organizational culture.

\section{LIMITATIONS AND RECOMMENDATIONS}

The limitations in this study are the research samples that only have scope in the automotive industry, in other industries that have different challenges and opportunities, these findings cannot be generalized. Future research is expected to accommodate limitations in this study so that the generalization area becomes wider. The OCB instrument developed in this study uses self-reports that have great subjectivity, in future studies OCB instruments are expected to be developed that consider the assessment of colleagues and superiors.

\section{CONCLUSION}

The general objective of this study was to investigate the effect of transformational leadership and organizational culture on organizational citizenship behavior through job satisfaction 
as a mediator variable. Data collection in this study uses four psychological scales, and the data analysis method used is path analysis. This study found that job satisfaction functions as a mediator of the influence of transformational leadership and organizational culture on organizational citizenship behavior.

The findings in this study reinforce the findings of the previous studies that are in line, that transformational leadership applied by indirect leaders has an effect on organizational citizenship behavior of employees, but will have an impact on job satisfaction first, then further job satisfaction will encourage the growth of organizational citizenship behavior of employees. Likewise with organizational culture, it will have an effect on organizational citizenship behavior after first cultivating employee job satisfaction. In other words, this study confirms that transformational leadership and existing organizational culture will affect employee job satisfaction which ultimately has a contribution to the growth of organizational citizenship behavior in employees.

\section{LIST OF ABBREVIATIONS}

$$
\begin{array}{ll}
\text { OCB } & =\text { Organizational Citizenship Behavior } \\
\text { TL } & =\text { Transformational Leadership } \\
\text { OC } & =\text { Organization Culture } \\
\text { JS } & =\text { Job Satisfaction } \\
\text { AVE } & =\text { Average Variance Extracted } \\
\text { SRMR } & =\text { Standardized Root Mean Square Residual }
\end{array}
$$

ETHICS APPROVAL AND CONSENT TO PARTICIPATE

Not applicable.

\section{HUMAN AND ANIMAL RIGHTS}

No animal/human was used for studies as the basis of research.

\section{CONSENT FOR PUBLICATION}

Not applicable.

\section{AVAILABILITY OF DATA AND MATERIALS}

Data are extracted from publicly available sources. Please contact the corresponding author if you need assistance in extracting the data.

\section{FUNDING}

None.

\section{CONFLICT OF INTEREST}

The authors declare no conflict of interest, financial or otherwise.

\section{ACKNOWLEDGMENTS}

Declared none.

\section{REFERENCES}

[1] Giorgi G, Arcangeli G, Mucci N, Cupelli V. 2014.Economic stress in workplace: The impact of fear the crisis on mental health, (March)
[2] Mucci N, Giorgi G, Perez J F, Arcangeli G. 2016; The correlation between stress and economic crisis: A systematic review 983-93.

[3] Nashori F. Psikologi Kepemimpinan. Yogyakarta: Pustaka Fahima 2009.

[4] Organizational citizenship behavior perusahaan Sultan Amal Press IAINSultan Amal Gorontolo 2015.

[5] Needle, David Business in Context: An Introduction to Business and Its Environment. New Delhi: McGraw-Hill 2004.

[6] Schein EH. Organizational Culture and Leadership. San Francisco: Jossey-Bass, Print 2010.

[7] Kim S, Yoon G. An innovation-driven culture in local government: Do senior manager's transformational leadership and the climate for creativity matter? Public Pers Manage 2015; 44(2): 147-68. [http://dx.doi.org/10.1177/0091026014568896]

[8] Aydin R A B. The role of organizational culture on leadership styles MANAS Journal of Social Studies 7(1)2018;

[9] Nohe C, Hertel G. Transformational leadership and organizational citizenship behavior: A meta-analytic test of underlying mechanisms Frontiers Media SA (CH) 2017.

[http://dx.doi.org/10.3389/fpsyg.2017.01364]

[10] Humprey A. - Issue 4. Taylor Francis Online 2012; 2012 [http://dx.doi.org/10.1080/10887156.2012.731831]]

[11] Lee YH, Woo B, Kim Y. Transformational leadership and organizational citizenship behavior: Mediating role of affective commitment. Journal, Local Government Studies. Taylor Francis Online 2017.

[12] Nohe C, Hertel G. Transformational leadership and organizational citizenship behavior: A meta-analytic test of underlying mechanisms Frontiers Media SA 2017.

[http://dx.doi.org/10.3389/fpsyg.2017.01364]

[13] Robbins SP, Judge TA. Organisational behavior. 12th ed. New Jersey: Pearson Internasional Edition 2007.

[14] Organ DW. Organizational Citizenship Behavior: The Good Soldier Syndrome. Lexington, MA: Lexington Books 2006.

[15] Graham J L. An Essay on Organizational Citizenship Behavior Employee Responsibilities and centers Journal 4(4): 249-70.1991; [http://dx.doi.org/10.1007/BF01385031]

[16] Podsakoff P M, MacKenzie S B, Paine J B, Bachrach D G. Organizational citizenship behaviors: A critical review of the theoretical and empirical literature and suggestions for future research Journal of Management 26(3): 513-63.2000; [http://dx.doi.org/10.1177/014920630002600307]

[17] Raziq A, Raheela MB. The impact of working environment on job satisfaction. Procedia Econ Finance 2014; 23.

[18] Ogaard T, Marnburg E, Larsen S. Perceptions of organizational structure in the hospitality industry: Consequences for commitment, job satisfaction and perceived performance. Tour Manage 2008; 29: 661-71.

[http://dx.doi.org/10.1016/j.tourman.2007.07.006]

[19] Opkara JO. The impact of salary differential on managerial job satisfaction. A study of the gender gap and its implications for management education and practice in a developing economy $\mathrm{J}$ Bus Dev Nation 2002; 65-92.

[20] Van der Voet J, Kuipers B S, Groeneveld S. Implementing change in public organizations: The relationship between leadership and affective commitment to change in a public sector context Pub Mana Rev 2016; 18(6): 842-65.

[21] Hasibuan MSP. Manajemen Sumber Daya Manusia. Jakarta: Bumi Aksara 2011

[22] O'Donnell O, Boyle R. Understanding and managing organization culture. Institute of Public Administration 2008.

[23] Belias D, Koustelios A, Vairaktarakis G, Sdrolias L. Organizational culture and job satisfaction of greek banking institutions. Procedia Soc Behav Sci 2015; 175: 314-23. [Published by Elsevier Ltd.]. [http://dx.doi.org/10.1016/j.sbspro.2015.01.1206]

[24] McLean LD. Organizational culture's influence on creativity and innovation: A review of the literature and implications for human resource development. Adv Dev Hum Resour 2012; 7(2) [http://dx.doi.org/10.1177/1523422305274528]

[25] Suifan TS, Al-Janini M. The relationship between transformational leadership and employees' creativity in the jordanian banking sector. Int Rev Manag Mark 2017; 7(2)

[26] Hofstede G. Cultures and Organizations: Software of the mind In: CA: Sage: BeverlyHills. 1991.

[27] Robbins SP, Judge TA. Organisational behavior. 12th ed. New Jersey: Pearson Internasional Edition 2007.

[28] Cacioppe R. Leadership moment by moment: Leadership and 
organization Development journal In: (7)335-45. 2000; 18: pp.

[29] Burns JM. Leadership. New York: Harper \& Row 1978.

[30] Rao MS. Transformational leadership - An academic case study. Ind Commer Train 2014; 46(3): 150-4.

[http://dx.doi.org/10.1108/ICT-07-2013-0043]

[31] Robbins SP, Judge TA. Organisational behavior. 12th ed. New Jersey: Pearson Internasional Edition 2007.

[32] Pawar BS. Central Conceptual issues, in transformational Leadership Research \& organization Development Journal 24(7): 397-406.2003;

[33] Van der Voet J, Kuipers B S, Groeneveld S. Implementing change in public organizations: The relationship between leadership and affective commitment to change in a public sector context Public Management Review 2016; 18(6): 842-65.

[34] Carmeli A, Reiter-Palmon R, Ziv E. Inclusive leadership and employee involvement in creative tasks in the workplace: The mediating role of psychological safety Creativity Research Journal 2010; 22(3): 250-260.217.

[35] Suifan TS, Al-Janini M. The Relationship between Transformational Leadership and Employees' Creativity in the Jordanian Banking Sector. Int Rev Manag Mark 2017; 7(2)

[36] Bass BM. Transformational leadership: Industrial, military, and educational impact. Mahwah, NJ: Erlbaum 1998.

[37] Newstrom J, Davis K. Organizational Behavior: Human behavior at work 2007.

[38] George JM, Jones GR. Understanding and managing organizational behavior. 5th ed. Pearson 2008.

[39] Raziq A, Raheela MB. The impact of working environment on job satisfaction. Procedia Econ Finance 2014; 23.

[40] Podsakoff M, Mackenzie S B, Moorman H. Leader behaviors and their effects on folower' trust in leader, satisfaction, and citizenship behaviors. (2): 107-42.1990;

[41] Halbesleben JRB, Wheeler AR. To invest or not? The role of coworker support and trust in daily reciprocal gain spirals of helping behavior. J Manage 2015; 2015(41): 1628-50. [http://dx.doi.org/10.1177/0149206312455246]

42] Jalilian H, Moradi M, Kamaei H. Transformational leadership and creativity of employees. Pol Hum Res 2010; 7(32): 59-72.

[43] Jahangir N, Akbar MM, Haq M. Organizational Citizenship Behavior. Its Nature And Antecendents 2004; I(2): 75-85.

[44] Nguni S, Sleegers P, Denessen E. Transformational and transactional leadership effects on teachers' job satisfaction, organizational commitment, and organizational citizenship behavior in primary schools: The Tanzanian case Transformational and Transactional Leadership Effects on Teachers ' Job Satisfaction, Organizational Commitment, and Organizational Citizenship Behavior in Primary Schools: The Tanzanian case 2007; 3453

[45] Mohanty J, Rath B P. Influen of Organizational Organizational Culture and Organizational Citizenship Behavior : A Three-Sector Study 6(1): 65-76.2012;

[46] Sarafraz S A, Kia A R. Examining the relationship between organizational culture and organizational citizenship behavior in the Social security branches of khorramabad 2015; 3(1): 368-76.

[47] Suparjo, Darmanto, S. Mediating Role of jobs satisfaction among organizational commitment, organizational Culture and Citizenship Behavior (OCB). Empirical Study on Private Higher Education in Central Java, Indonesia 2015; 4(1): 289-96.

[48] Giorgi G, Arcangeli G, Mucci N, Cupelli V. Economic stress in workplace: The impact of fear the crisis on mental health, (March) 2014.

[49] Kar DP, Tewari HR. Organizational culture and organizational citizenship 2014; 34(4): 421-33.

[50] Wang HUI, Law KS, Hackett RD, Wang D, Chen ZX. Leader-member exchage as a mediator of the relationship between transformational leadership and folowers'. Per and Org Citi Behav 2005; 48(3): 420-32.

[51] Kaliski BS. Encyclopedia of Business and Finance. 2nd ed. Detroit: Thompson Gale 2007; p. 446.

[52] Sarafraz S A, Kia A R. Examining the relationship between organizational culture and organizational citizenship behavior in the social security branches of khorramabad 32015; (1)368: 376.

(c) 2019 Aldrin and Yunanto.

This is an open access article distributed under the terms of the Creative Commons Attribution 4.0 International Public License (CC-BY 4.0), a copy of which is available at: https://creativecommons.org/licenses/by/4.0/legalcode. This license permits unrestricted use, distribution, and reproduction in any medium, provided the original author and source are credited. 